\title{
Berpikir untuk memilih Fokus yang Benar Ditinjau dari Teori Belajar Konstruktivisme
}

\author{
Vally Manafe, Vanny Oktaviany
}

\begin{abstract}
Abstrak
Konstruktivisme adalah belajar melebihi pemahaman yang wajar. Struktur kognitif yang berkembang dan dikonstruksi kembali dengan pemahaman peserta didik. Peserta didik memilih fokus pada proses pembelajaran daripada terfokus dengan apa yang ada di sekelilingnya. Fokus pada apa yang dianggap benar, namun ternyata ada yang lebih penting daripada yang dipikirkan. Peserta didik diberi kesempatan untuk berpikir kritis, dan memikirkan kembali apa yang dapat dilakukan untuk suatu ide atau gagasan yang lebih benar, dan tepat untuk dilakukan dalam perbuatan.
\end{abstract}

Kata-kata kunci: pikiran, kritis, konstruktivisme, prioritas, fokus, belajar

\section{Pendahuluan}

\section{A. Latar Belakang}

Di dalam proses pembelajaran, munculnya kesulitan untuk memahami suatu konsep merupakan hal yang wajar. Ini menggambarkan bahwa anak sedang melakukan proses berpikir. Mereka berusaha untuk mengintegrasikan informasi baru ke dalam struktur kognitif yang telah dimilikinya. Skemata atau pengetahuan awal setiap siswa tidaklah sama sehingga kesulitan yang setiap anak pun tidaklah selalu sama. Sebagai seorang guru atau orang yang membimbing mereka belajar, sebaiknya kita dapat mengenali dan memahami kesulitan-kesulitan yang dihadapi oleh anak. Karena jika dibiarkan kesulitan tersebut tidak lagi menjadi sebuah kewajaran, melainkan suatu masalah yang dapat menghambat perkembangan intelektual anak.

Berpikir untuk berubah berarti belajar untuk berubah. Tidak hanya mementingkan kognitif semata tetapi juga sikap dan motivasi siswa untuk mengikuti proses pembelajaran. Siswa termotivasi aktif di kelas untuk meningkatkan hasil belajarnya. Motivasi dari dalam dirinya membantu untuk berpikir, bersikap, dan bertindak (Sahiu \& Wijaya, 2017).

\section{Kajian Teori}

\section{A. Pengertian Konstruktivisme}

Asal kata konstruktivisme adalah "to construct" yang artinya membangun atau menyusun. Dalam konteks filsafat pendidikan, Konstruktivisme adalah suatu upaya membangun tata susunan hidup yang berbudaya modern. Konstruktivisme adalah suatu filsafat belajar yang dibangun atas anggapan bahwa dengan memfreksikan pengalamanpengalaman Teori konstruktif (menurut istilah Einsten, 1934, dan Marx, 1951) atau teori merangkaikan/Concatenated (Kaplan, 1964), yaitu "Teori yang mencoba membangun kaitan-kaitan (sintesis) antara berbagai fenomena sederhana". 
Teori konstruktivisme didefinisikan sebagai pembelajaran yang bersifat generatif, yaitu tindakan mencipta sesuatu makna dari apa yang dipelajari. Konstruktivisme sebenarnya bukan merupakan gagasan yang baru, apa yang dilalui dalam kehidupan kita selama ini merupakan himpunan dan pembinaan pengalaman demi pengalaman. Ini menyebabkan seseorang mempunyai pengetahuan dan menjadi lebih dinamis.

Dari keterangan di atas dapat disimpulan bahwa teori ini memberikan keaktifanterhadap peserta didik untuk belajar menemukan sendiri kompetensi, pengetahuan atau teknologi, dan hal lain yang diperlukan guna mengembangkan dirinya sendiri. Menurut Wheatley (1991: 12) berpendapat dengan mengajukan dua prinsip utama dalam pembelajaran dengan teori belajar konstrukltivisme.

Pertama, pengetahuan tidak dapat diperoleh secara pasif, tetapi secara aktif oleh struktur kognitif siswa. Kedua, fungsi kognisi bersifat adaptif dan membantu pengorganisasian melalui pengalaman nyata yang dimiliki anak. Dari pengertian di atas menekankan bagaimana pentingnya keterlibatan anak secara aktif dalam proses pengaitan sejumlah gagasan dan pengkonstruksian ilmu pengetahuan melalui lingkungannya. Bahkan secara spesifik Hudoyo (1990: 4) mengatakan bahwa seseorang akan lebih mudah mempelajari sesuatu bila belajar itu didasari kepada apa yang telah diketahui orang lain. Oleh karena itu, untuk mempelajari suatu materi yang baru, pengalaman belajar yang lalu dari seseorang akan mempengaruhi terjadinya proses belajar tersebut.

\section{B. Ciri-ciri Konstruktivisme}

1. Pengetahuan dibangun oleh siswa sendiri.

2. Pengetahuan tidak dapat dipindahkan dari guru ke murid, kecuali hanya dengan keaktifan murid sendiri untuk menalar.

3. Murid aktif megkontruksi secara terus menerus, sehingga selalu terjadi perubahan konsep

ilmiah.

4. Guru sekadar membantu menyediakan saran dan situasi agar proses kontruksi berjalan lancar.

5. Struktur pembalajaran seputar konsep utama pentingnya sebuah pertanyaan.

Selain itu yang paling penting adalah guru tidak boleh hanya semata-mata memberikan

pengetahuan kepada siswa. siswa harus membangun pengetahuan didalam benaknya sendiri. Seorang guru dapat membantu proses ini dengan cara-cara mengajar yang membuat informasi

menjadi sangat bermakna dan sangat relevan bagi siswa, dengan memberikan kesempatan kepada siswa untuk menemukan atau menerapkan sendiri ide-ide dan dengan mengajak siswa agar menyadari dan menggunakan strategi-strategi mereka sendiri untuk belajar. Guru dapat memberikan tangga kepada siswa yang mana tangga itu nantinya dimaksudkan dapat membantu mereka mencapai tingkat pemahaman yang lebih tinggi, tetapi harus diupayakan agar siswa itu sendiri yang memanjatnya.

Pendidikan neuroscience membantu proses berpikir kritis siswa untuk menanyakan, dan memberikan pendapatnya tentang apa yang mereka lihat, rasakan, dan lakukan dalam pengalaman nyata (Wijaya, 2018). Oleh karena itu, siswa ditantang untuk mendemostrasikan pengalamannya di kelas baik secara berpasangan, maupun kepada semua teman sebayanya. 
Piaget menyatakan bahwa "Ilmu pengetahuan dibangun dalam pikiran seorang anak dengan kegiatan asimilasi dan akomodasi sesuai dengan skemata yang dimilikinya". Proses tersebut meliputi:

a. Skema/skemata adalah struktur kognitif yang dengannya seseorang beradaptasi dan terus mengalami perkembangan mental dalam interaksinya dengan lingkungan. Skema juga berfungsi sebagai kategori-kategori utnuk mengidentifikasikan rangsangan yang datang, dan terus berkembang.

b. Asimilasi adalah proses kognitif perubahan skema yang tetap mempertahankan konsep awalnya, hanya menambah atau merinci.

c. Akomodasi adalah proses pembentukan skema atau karena konsep awal sudah tidak cocok lagi.

d. Equilibrasi adalah keseimbangan antara asimilasi dan akomodasi sehingga seseorang dapat menyatukan pengalaman luar dengan struktur dalamya (skemata). Proses perkembangan intelek seseorang berjalan dari disequilibrium menuju equilibrium melalui asimilasi dan akomodasi.

Lebih jauh Piaget mengemukakan bahwa pengetahuan tidak diperoleh secara pasif oleh seseorang, melainkan melalui tindakan. Belajar merupakan proses untuk membangun penghayatan terhadap suatu materi yang disampaikan. Bahkan, perkembangan kognitif anak bergantung pada seberapa jauh mereka aktif memanipulasi dan berinteraksi dengan lingkungannya. Sedangkan, perkembangan kognitif itu sendiri merupakan proses berkesinambungan tentang keadaan ketidak-seimbangan dan keadaan keseimbangan (Poedjiadi, 1999: 61).

Dari pandangan Piaget tentang tahap perkembangan kognitif anak dapat dipahami bahwa pada tahap tertentu cara maupun kemampuan anak mengkonstruksi ilmu berbeda- kematangan intelektual anak. Pada teori ini konsekuensinya adalah siswa harus memiliki keterampilan unutk menyesuaikan diri atau adaptasi secara tepat.

\section{Prinsip-Prinsip Konstruktivisme}

Secara garis besar, prinsip-prinsip Konstruktivisme yang diterapkan dalam belajar mengajar adalah:

1. Pengetahuan dibangun oleh siswa sendiri.

2. Pengetahuan tidak dapat dipindahkan dari guru kemurid, kecuali hanya dengan keaktifan murid sendiri untuk menalar.

3. Murid aktif megkontruksi secara terus menerus, sehingga selalu terjadi perubahan konsep ilmiah.

4. Guru sekedar membantu menyediakan saran dan situasi agar proses kontruksi berjalan lancar.

5. Menghadapi masalah yang relevan dengan siswa

6. Struktur pembelajaran seputar konsep utama pentingnya sebuah pertanyaan

7. Mencari dan menilai pendapat siswa

8. Menyesuaikan kurikulum untuk menanggapi anggapan siswa.

Dari semua itu hanya ada satu prinsip yang paling penting adalah guru tidak boleh hanya semata-mata memberikan pengetahuan kepada siswa. Siswa harus membangun pengetahuan di dalam benaknya sendiri. Seorang guru dapat membantu proses ini dengan cara-cara mengajar yang membuat informasi menjadi sangat bermakna dan sangat relevan bagi siswa, dengan memberikan kesempatan kepada siswa untuk menemukan atau menerapkan sendiri ide-ide dan dengan mengajak siswa agar 
menyadari, dan menggunakan strategi-strategi mereka sendiri untuk belajar. Guru dapat memberikan tangga kepada siswa yang mana tangga itu nantinya dimaksudkan dapat membantu mereka mencapai tingkat penemuan.

\section{Tujuan Teori Konstruktivisme di Kelas}

1. Adanya motivasi untuk siswa bahwa belajar adalah tanggung jawab siswa itu sendiri.

2. Mengembangkan kemampuan siswa untuk mengajukan pertanyaan dan mencari sendiri pertanyaannya.

3. Membantu siswa untuk mengembangkan pengertian, dan pemahaman konsep secara lengkap.

4. Mengembangkan kemampuan siswa untuk menjadi pemikir yang mandiri.

5. Lebih menekankan pada proses belajar bagaimana belajar itu.

\section{E. Implikasi Teori Konstruktivisme dalam Pendidikan}

1. Mendorong kemandirian dan inisiatif siswa dalam belajar Dengan menghargai gagasa-gagasan atau pemikiran siswa serta mendorong siswa berpikir mandiri, berarti guru membantu siswa menemukan identitas intelektual mereka. Para siswa yang merumuskan pertanyaan-pertanyaan dan kemudian menganalisis serta menjawabnya berarti telah mengembangkan tanggung jawab terhadap proses belajar mereka sendiri serta menjadi pemecah masalah (problem solver). Guru mengajukan pertanyaan terbuka dan memberikan kesempatan beberapa waktu kepada ssiswa untuk merespons. Berpikir reflektif memerlukan waktu yang cukup dan seringkali atas dasar gagasan-gagasan dan komentar orang lain. Cara-cara guru mengajukan pertanyaan dan cara siswa merespons atau menjawabnya akan mendorong siswa mampu membangun keberhasilan dalam melakukan penyelidikan.

2. Mendorong siswa berpikir tingkat tinggi

Guru yang menerapkan proses pembelajaran konstruktivisme akan menantang para siswa untuk mampu menjangkau hal-hal yang berada di balik respon-respon faktual yang sederhana. Guru mendorong siswa untuk menghubungkan dan merangkum konsep-konsep melalui analisis, prediksi, justifikasi, dan mempertahankan gagasangagasan atau pemikirannya.

3. Siswa terlibat secara aktif dalam dialog atau didkusi dengan guru dan siswa lainnya Dialog dan diskusi yang merupakan interaksi sosial dalam kelas yang bersifat intensif sangat membantu siswa untuk mampu mengubah atau menguatkan gagasangagasannya. Jika mereka memiliki kesempatan untuk mengemukakan apa yang mereka pikirkan dan mendengarkan gagasan-gagasan orang lain, maka mereka akan mampu membangun pengetahuannya sendiri yang didasarkan atas pemahaman mereka sendiri. Jika mereka merasa aman dan nyaman untuk mengemukakan gagasannya maka dialog yang sangat bermakna akan terjadi di kelas.

4. Siswa terlibat dalam pengalaman yang menantang dan mendorong terjadinya diskusi Jika diberi kesempatan untuk membuat berbagai macam prediksi, seringkali siswa menghasilkan berbagai hipotesis tentang fenomena alam ini. Guru yang menerapkan konstruktivisme dalam belajar memberikan kesempatan seluas-luasnya kepada siswa untuk menguji hpotesis yang mereka buat, terutama melalu diskusi kelompok dan pengalaman nyata.

5. Guru memberika data mentah, sumber-sumber utama, dan materi-materi interaktif Proses pembelajaran yang menerapkan pendekatan konstruktivisme melibatkan para siswa dalam mengamati dan menganalisis fenomena alam dalam dunia nyata. 
Kemudian guru membantu para siswa untuk menghasilkan abstraksi atau pemikiranpemikiran tentang fenomena-fenomena alam tersebut secara bersama-sama.

\section{Metode}

Metode penulisan makalah ini adalah kajian kualitatif. Kajian kualitatif deskriptif sederhana yang menggunakan alat bantu literatur yang berkaitan dengan topik yang akan dibahas (Wijaya, 2018). Selanjutnya data-data yang berupa literasi dibangkitkan dengan memberikan hubungan-hubungan satu referensi dengan referensi lainnya berupa sintesis dari kumpulan definisi, teori, dan hasil penelitian (Wijaya \& Helaluddin, 2019).

Tulisan ini akan menghubungkan teori konstruktivisme dengan kajaian hermeneutik Perjanjian Baru yang terambil dari kisah Maria dan Marta. Ekposisi

Alkitab adalah salah satu metode penafsiran Alkitab secara sederhana (Wijaya, 2013). Hasil eksposisi tersebut dinarasikan berdasarkan konteks Alkitab dan implikasinya saat ini dan melihat relevansinya dengan teori konstruktivisme yang menekankan cara pemikiran yang tidak biasa atau melebihi pemikiran yang sederhana.

Model pembelajaran yang dapat dilakukan adalah model pembelajaran kooperatif STAD (Wijaya \& Arismunandar, 2018), dan juga sangat memungkinkan model pembelajaran Think Pair Share untuk meningkatkan kemampuan berpikir kritis (Kule \& Wijaya, 2018).

\section{Pembahasan}

\section{Hubungan Teori Konstruktivisme dengan Pembelajaran dari Maria dan Marta}

(Lukas 10: $38-42$ )

Dalam teori konstruktivisme adalah serangkaian bagian, definisi, dan dalil yang saling berhubungan yang menghadirkan sebuah pandangan sistematis mengenai fenomena dengan menentukan hubungan antar variabel, dengan maksud menjelaskan fenomena alamiah. Ide pemikiran yang "menentukan" bagaimana dan mengapa dan pernyataan hubungan dapat saling berhubungan.

Sekarang kita mencoba membandingkan jalan yang ditempuh Marta dan jalan yang ditempuh Maria. Narasi cerita bahwa baik Marta maupun Maria adalah dua orang yang melayani Tuhan. Tetapi pelayanan mereka berbeda dalam hal fokusnya. Fokus pelayanan Maria adalah pribadi Tuhan sendiri, sedangkan fokus pelayanan Marta adalah kebutuhan-kebutuhan atau kepentingan-kepentingan Tuhan. Ada perbedaan yang besar antara pribadi Tuhan dan kepentingan Tuhan. Memang kepentingan Tuhan agar orangorang miskin dilayani, karena Tuhan mencintai orang-orang miskin. Memang kepentingan Tuhan bahwa jiwa-jiwa diselamatkan, karena Ia datang kedunia untuk menyelamatkan jiwa-jiwa. Tetapi Tuhan juga mempunyai kerinduan agar orang datang kepada Diri-Nya dan memecahkan "buli-buli" mereka bagiNya. Pelayanan Marta terfokus kepada "orang-orang miskin", atau jiwa-jiwa, tetapi pelayanan Maria terfokus kepada Tuhan sendiri. Perlu kita ingat bahwa pelayanan Marta adalah baik, tetapi pelayanan Maria adalah yang terbaik.

Apakah seseorang menempuh jalan pelayanan Marta atau Maria, semua tergantung pilihan masing-masing. Karena ditegaskan bahwa,“...Maria telah memilih 
bagian yang terbaik". Jadi, terserah kepada kita. Namun, berbahagialah kita, jika kita telah memilih jalan yang terbaik.

Beberapa mahasiswa menyadari perubahan tersebut. Ada yang berpendapat bahwa apa yang menjadi fokus penyembahan dating kepada Tuhan. Apakah mencari tangan-Nya (berkat, dan kuasa-Nya)? Atau orang percaya mencari wajah-Nya (2 Taw 7:14). Tison \& Djadi, (2013) menjelaskan bahwa tujuan ibadah (penyembahan) kepada Allah adalah untuk bersekutu dengan-Nya. Maria memilih untuk duduk di kaki Yesus untuk sebuah prioritas yang terutama. Allah telah hadir Bersama dengan Maria dan kesempatan ini digunakannya untuk lebih mengenal Yesus. Wijaya, (2015) menyatakan menjadi penyembah benar adalah menyembah Dia dalam Roh dan kebenaran. Kebenarannya adalah bahwa Maria mengetahui bahwa Yesus adalah Tuhan, dan dia sepatutnya bersama dengan Tuhan. Apa yang akan diubahkan ketika Maria ada bersama Yesus? Hati Maria akan diubahkan seperti yang dikehendaki oleh Yesus. Bagi orang percaya perubahan karakter hanya dapat dilakukan melalui proses belajar yang disengaja, dan dikaruniakan oleh Roh Kudus (Wijaya, 2017).

Wijaya \& Helaluddin, (2018) menyatakan bahwa salah satu tujuan Pendidikan karakter adalah bertakwa kepada Tuhan Yang Maha Esa. Oleh karena itu, orang percaya terlebih dahulu memprioritaskan Tuhan di atas segalanya sehingga pekerjaan-pekerjaan Tuhan dapat dilakukan dengan efektif, dan sesuai dengan kehendak Tuhan.

Dalam kisah Maria dan Marta dalam hubungan Teori belajar Konstruktivistik di dunia Pendidikan disimpulkan bahwa siswa dimotivasi untuk berpikir kritis dengan pengambilan keputusan untuk memilih segala hal dengan skala prioritas terutama. Apa yang dilakukan oleh Marta dalam pemikiran manusia adalah benar adanya. Namun adakalanya bukan menjadi prioritas. Guru harus mendidik siswa untuk mendahulukan yang terbaik sehingga cara berpikir mereka selalu diarahkan kepada yang terutama, primer, dan bersifat kekekalan.

\section{Implikasinya Bagi Pendidikan Anak}

Sebagai guru Kristen memelihi prioritas membawa anak didiknya untuk mengenal Tuhan. Sebab Tuhan sumber hikmat yang dapat mengembangkan pola pikir siswa ke arah yang lebih baik. Tentu guru harus menganalisis kebutuhan siswanya dan mengembangkan potensinya. Namun terlebih dahulu mendidik siswa untuk berpikir kritis sesuai dengan kebenaran Alkitab. Untuk itulah guru harus memahami siswanya yang ada di zaman milenial ini dengan kemajuan IT dan hiruk pikuk media sosial yang berpengaruh nyata kepada anak didik.

Kompetensi guru untuk lebih mengenal siswanya menjadi prioritas untuk mengembangkan potensi anak, dan mendidiknya dalam pertumbuhannya. Guru harus mampu menjadi konselor, memiliki kemampuan IT, kemampuan pendidik (professional, sosial, pedagogik) (Helaluddin \& Wijaya, 2019). Tujuannya untuk melayani anak-anak milenial maka dibutuhkan pelayanan Cyber Smart parenting untuk mencegah kecanduan media sosial (Wadi \& Selfina, 2016). Pola pikir anak bisa distimulus dengan melibatkan mereka dalam kegiatan rohani seperti bernyanyi, paduan suara sehingga perilaku mereka sejak dini dapat diarahkan kepada hal-hal yang rohani dan berdampak pada pertumbuhan rohani mereka (Siahaan, 2013).

Hubungan pola pikir kritis menentukan sikap dan karakter seseorang dalam melakukan tindakannya (Matchett, 2009). Karakter menjadi urgen dalam Pendidikan. Karakter menjadi prioritas dalam Pendidikan. Oleh karena itu melalui Pendidikan Agama Kristen, guru hendaknya menfokuskan bahan ajarnya di dalam kelas pada Allah dan implikasinya dalam Pendidikan anak dan remaja yang membutuhkan bimbingan 
dan arah yang tepat untuk perubahan tingkah laku mereka yang dimulai dengan perubahan metanoia di otak mereka. Dampaknya adalah pengambilan keputusan tepat untuk menentukan sikap dan perilaku yang benar di hadapan Tuhan dan sesama, bertumbuh di dalam Kristus (Matheus \& Selfina, 2015).

\section{Kesimpulan}

Pendekatan pengajaran dan pembelajaran yang berasaskan Konstruktivisme akan memberi peluang kepada guru untuk memilih kaidah pengajaran dan pembelajaran yang sesuai dan murid dapat menentukan sendiri apa yang diperlukan untuk memperoleh suatu konsep atau pengetahuan. Di samping itu, guru dapat membuat penilaian sendiri dan menilai kepahamannya tentang sesuatu bidang pengetahuan dapat ditingkatkan lagi. Guru menggunakan firman Tuhan untuk melihat seberapa besar kemampuan siswa untuk berpikir kritis untuk menentukan sikap, karakter, perilaku yang akan dilaksanakan baik di kelas, maupun di luar kelas.

Pembelajaran konstruktivisme tidak hanya mengisi pengetahuan di otak (kognitif), tetapi juga berpikir kritis untuk mengembangkan cara berpikir siswa untuk menentukan pola pikir, sikap, dan perbuatan yang akan dilaksanakannya. Apabila sikapnya seperti Maria maka guru sudah mendapati siswa yang berani mengambil prioritas terutama dalam hidupnya. Dapat Tuhan Yesus dapat semuanya. Tuhan sumber hikmat, dan kehendak-Nya harus jadi dalam diri guru, dan murid-murid. 


\section{DAFTAR PUSTAKA}

Helaluddin, H., \& Wijaya, H. (2019). Pengembangan Kompetensi Pendidik Di Perguruan Tinggi Dalam Menyonsong Era Revolusi Industri 4.0. Retrieved November 19, 2019, from https://repository.sttjaffray.ac.id/id/publications/273069/pengembangankompetensi-pendidik-di-perguruan-tinggi-dalam-menyonsong-era-revolu

Kule, K., \& Wijaya, H. (2018). Penerapan Model Pembelajaran Cooperative Learning Tipe Think Pair Share Pada Materi Listrik Dinamis Untuk Meningkatkan Hasil Belajar Siswa Kelas XI TKR1 SMK Negeri 2 Tarakan. Jurnal Ilmu Pendidikan Fisika (JIPF), 3(2), 47-51.

Matchett, N. J. (2009). Cooperative Learning, Critical Thinking, and Character: Techniques to Cultivate Ethical Deliberation. Public Integrity, 12(1), 25-38. doi: 10.2753/PIN1099-9922120102

Matheus, J., \& Selfina, E. (2015). Peran Pembina Remaja Bagi Perkembangan Perilaku Remaja Di Gereja Kemah Injil Indonesia Tanjung Selor Kalimantan Utara. Jurnal Jaffray, 13(1), 1-22. doi: 10.25278/jj71.v13i1.3

Ronda, Daniel. (2013). Dasar Teologi yang Teguh: Panduan Teologi Sistematika Di Perguruan Tinggi. Makassar: Sekolah Tinggi Theologia Jaffray.

Sahiu, S., \& Wijaya, H. (2017). Hubungan Motivasi Belajar Ekstrinsik Terhadap Hasil Belajar Psikomotorik Pada Mata Pelajaran Agama Kristen Kelas V Di SD Zion Makassar. Jurnal Jaffray, 15(2), 231. doi: 10.25278/jj71.v15i2.262

Siahaan, R. (2013). Analisis Pengaruh Nyanyian Jemaat Terhadap Kualitas Ibadah Gereja Protestan di Indonesia bagian Barat (GPIB) Jemaat Bukit Zaitun Makassar. Jurnal Jaffray, 11(2), 140-164. doi: 10.25278/jj71.v11i2.82

Tison, T., \& Djadi, J. (2013). Pengajaran Tentang Ibadah Berdasarkan Surat Ibrani 10:19-25 Dan Implimentasinya Dalam Kehidupan Orang Percaya Pada Masa Kini. Jurnal Jaffray, 11(1), 37-66. doi: 10.25278/jj71.v11i1.67

Wadi, E. N., \& Selfina, E. (2016). Peran Orang Tua Sebagai Keluarga Cyber Smart Dalam Mengajarkan Pendidikan Kristen Pada Remaja GKII Ebenhaezer Sentani Jayapura Papua. Jurnal Jaffray, 14(1), 77-92. doi: 10.25278/jj71.v14i1.190

Wijaya, H. (2013). Metode Penelitian Pendidikan Teologi. Makassar: Sekolah Tinggi Theologia Jaffray Makassar.

Wijaya, H. (2015). Kajian Teologis Tentang Penyembahan Berdasarkan Injil Yohanes 4:24. Jurnal Jaffray, 13(1), 77. doi: 10.25278/jj71.v13i1.112

Wijaya, H. (2017). Ulasan Buku: Whatever Happened To Worship A Call To True Worship. Jurnal Jaffray, 15(1), 148. doi: 10.25278/jj71.v15i1.241

Wijaya, H. (2018). Analisis Data Kualitatif Ilmu Pendidikan Teologi. Makassar: Sekolah Tinggi Theologia Jaffray Makassar.

Wijaya, H. (2018). Pendidikan Neurosains Dan Implikasinya Dalam Pendidikan Masa Kini. Retrieved from https://repository.sttjaffray.ac.id/media/269017pendidikan-neurosains-dan-implikasinya-d-5854b17f.pdf

Wijaya, H., \& Arismunandar, A. (2018). Pengembangan Model Pembelajaran Kooperatif Tipe STAD Berbasis Media Sosial. Jurnal Jaffray, 16(2), 175-196. doi: $10.25278 / \mathrm{jj} 71 . v 16 \mathrm{i} 2.302$

Wijaya, H., \& Helaluddin, H. (2018). Hakikat Pendidikan Karakter. Retrieved from https://repository.sttjaffray.ac.id/id/publications/269450/hakikat-pendidikankarakter 
Wijaya, H., \& Helaluddin, H. (2019). Analisis Data Kualitatif Sebuah Tinjauan Teori \& Praktik. Makassar: Sekolah Tinggi Theologia Jaffray Makassar. 